\title{
Effect of Different Supplementation Levels of Soybean Flour on Pearl Millet Functional Properties
}

\author{
Maha A. M. Ali ${ }^{1}$, Abdullahi H. El Tinay ${ }^{1}$, Abd Elmoneim O. Elkhalifa ${ }^{2 *}$, Limya O. Mallasy ${ }^{1}$, \\ Elfadil E. Babiker ${ }^{1}$ \\ ${ }^{1}$ Department of Food Science and Technology, Faculty of Agriculture, University of Khartoum, Khartoum, Sudan, ${ }^{2}$ Ahfad University \\ for Women, Omdurman, Sudan. \\ Email: ${ }^{*}$ aoelkhalifa@hotmail.com
}

Received August $9^{\text {th }}, 2010$; revised November $30^{\text {th }}, 2011$; accepted December $7^{\text {th }}, 2011$

\begin{abstract}
Pearl millet cultivar (Dempy) was supplemented with soybean flour to raise the protein content by $5 \%, 10 \%$ and $15 \%$. Defatted soybean flour, pearl millet flour and their composite flour had varying functional properties. Water and fat absorption, bulk density, nitrogen solubility and dispersibility were higher for soybean flour compared to that of pearl millet flour. Therefore, such properties were improved significantly $(\mathrm{P} \leq 0.05)$ for pearl millet with increasing the level of soybean supplementation. The emulsifying and foaming properties of pearl millet flour were poor but after supplementation with soybean they significantly $(\mathrm{P} \leq 0.05)$ improved. Supplementation of pearl millet flour with soybean had no effect on least gelation concentration of millet. The implication of these results will be realized in designing proteinenriched products based on pearl millet flour, especially for pearl millet-growing regions in the under-developing countries.
\end{abstract}

Keywords: Pearl Millet; Soybean; Supplementation; Functional Properties

\section{Introduction}

Millets have been important staples in the semi-arid tropics of Asia and Africa for centuries. It will continue to be the major food crop in several countries, especially in Africa and, in particular, in Nigeria and Sudan [1]. Pearl millet (Pennisetum glaucum (L.) R. Br.) is the most widely grown product of the millet species. Pearl millet has some potential for industrial use; other millets have limited potential because of their small grain size and the associated difficulties of adopting a suitable dehulling technology [1]. The soybean (Glycine max) is the seed of the leguminous soybean plant. It has high protein content and is not very expensive. Therefore, it has been proposed as an ideal source for protein supplementation of starchy foods [2]. To improve the nutritional quality of cereal-based traditional diets in Africa, the use of soybean flour as a protein supplement has often been suggested. Supplementation of pearl millet flour with soybean flour makes it nutritionally superior and produces acceptable food products. Functionality of food proteins is defined as those physical and chemical properties, which affect the behavior of proteins in food systems during processing, storage, preparation and consumption [3]. A functional property is any non-nutritional property

\footnotetext{
"Corresponding author.
}

of a food additive that affects its utilization [4]. Soybean proteins have been used widely in foods for their distinctive physiochemical and functional properties as well as nutritional values [5]. Soybean proteins are available to the food industry in the form of flours and grits concentrates and isolates with respective protein contents of $40 \%-50 \%, 70 \%$ and $90 \%$ or more. These proteins, when added to a variety of foods, supply desirable functional properties, such as emulsification, fat absorption, moisture holding, thickening and foaming [6]. However, information on the functional properties of pearl millet flour as fortified with soybean protein is needed in view of its increased utilization as a dietary component. Therefore, the objective of this study was to investigate the effect of supplementation with soybean protein on functional properties of pearl millet flour.

\section{Materials and Methods}

\subsection{Materials}

Soybean flour was obtained from a supermarket in New York, USA, having protein content of $38.7 \%$. Pearl millet cultivar Dempy was obtained from El Obeid Research Station, Sudan, having protein content of $13.0 \%$. The seeds were harvested during the season 2006-2007. All 
chemicals used in this study were of reagent grade.

\subsection{Functional Properties}

\subsubsection{Water Absorption Capacity}

The water absorption capacity (WAC) was estimated by the method of Lin et al. [7] with a modification described by Quinn \& Beuchat [8].

\subsubsection{Bulk Density}

The bulk density (BD) was determined by the method of Wang \& Kinsella [9].

\subsubsection{Nitrogen Solubility}

Nitrogen solubility (NS) was determined by the procedure of Haegenmair [10], as described by Quinn \& Beuchat [8], with a slight modification. Exactly 0.2 grams of material were dispersed in $10 \mathrm{ml}$ distilled water with continuous shaking at room temperature. After 1.0 hour the suspension was centrifuged at $3000 \mathrm{rpm}$ for $20 \mathrm{~min}-$ utes at room temperature. The soluble nitrogen in the supernatant was estimated by micro-Kjeldahl method. Nitrogen solubility was expressed as a percentage of the total nitrogen.

\subsubsection{Emulsifying Properties}

2.2.4.1. Emulsifying Capacity

The emulsifying capacity was estimated by the method of Beuchat et al. [11].

\subsubsection{Emulsifying Activity (EA) and Emulsion Stability (ES)}

The emulsification activity (EA) was measured by the procedure of Yausumatsu et al. [12], with a slight modification. About 0.7 gram of material was added to $10 \mathrm{ml}$ distilled water and mixed well before adding $10 \mathrm{ml}$ of refined corn oil. The mixture was blended in a Braun electric blender for 5 minutes, poured into centrifuge tubes and centrifuged at $2000 \mathrm{rpm}$ for 5 minutes. EA was expressed as:

$$
\mathrm{EA}(\%)=\frac{\text { Height of emulsion } \times 100}{\text { Height of whole layer }}
$$

Emulsion stability (ES) was measured by recentrifugation followed by heating at $80^{\circ} \mathrm{C}$ for 30 minutes, and subsequently, cooled to $15^{\circ} \mathrm{C}$. ES was expressed as the percentage of the total volume remaining emulsified after heating:

$$
\mathrm{ES}(\%)=\frac{\text { Height of emulsion layer after heating } \times 100}{\text { Height of whole layer }}
$$

\subsubsection{Foaming Properties}

2.2.5.1. Foaming Capacity (FC)

The Foaming capacity (FC) of the sample was deter- mined by the procedure described by Lawhon et al. [13]

\subsubsection{Foam Stability (FS)}

The foam stability (FS) was conducted according to Ahmed \& Schmidt [14]. The FS was recorded at $15 \mathrm{~min}$ intervals for $90 \mathrm{~min}$ after pouring the material in a cylinder:

$$
\mathrm{FS}(\%)=\frac{\text { Foam volume after time }(\mathrm{t}) \times 100}{\text { Initial foam volume }}
$$

\subsubsection{Gelation}

The least gelation concentration of the sample was measured by the method of Coffman \& Garcia [15], with a slight modification. Appropriate sample suspensions of $2 \%, 4 \%, 6 \%, 8 \%$ and $10 \%$ were prepared in $10 \mathrm{ml}$ of distilled water. The test tubes containing these suspensions were then heated for one hour in a boiling water bath, followed by rapid cooling under running cold tap water. The test tubes were further cooled for 3 hours at $\left(4^{\circ} \mathrm{C}\right)$. The least gellation concentration was determined as that concentration which did not fall down or slip when the test tube was inverted.

\subsubsection{Dispersibility}

The dispersibility of flour at selected $\mathrm{pH}$ levels $(3,7$ and 10) was measured according to the method of Kulkani et al. [16].

\subsubsection{Wettability}

The wettability was estimated according to the method of Regenstein \& Regenstein [17].

\subsection{Statistical Analysis}

Each determination consisted of three separate samples, which were analyzed, and the figures were then averaged. Data were assessed by analysis of variance (ANOVA) [18] and by the Duncan's multiple range test with a probability $\mathrm{P} \leq 0.05$ [19].

\section{Results and Discussion}

\subsection{Physical Functional Properties}

The physical functional properties of pearl millet, soybean and pearl millet supplement is shown in Table 1 . The bulk density (BD) improved significantly for pearl millet with increasing the level of soybean protein supplement. The results indicated that supplementation of pearl millet with soybean protein improved significantly $(\mathrm{P} \leq 0.05)$ the bulk density of millet. A higher BD is desirable, since it helps to reduce the paste thickness which is an important factor in convalescent and child feeding [20]. Densh [21] reported that BD of defatted soybean flour was $0.46 \mathrm{~g} / \mathrm{ml}$, while Bryant et al. [22] reported 
Table 1. Bulk density (BD), water absorption capacity (WAC), fat absorption capacity (FAC) and nitrogen solubility (NS) of defatted pearl millet flour, soybean flour and pearl millet supplemented with $5 \%, 10 \%$ and $15 \%$ soybean flour.

\begin{tabular}{ccccc}
\hline Sample & $\mathrm{BD}(\mathrm{g} / \mathrm{ml})$ & WAC $(\mathrm{ml} / 100 \mathrm{~g})$ & $\mathrm{FAC}(\mathrm{ml} / 100 \mathrm{~g})$ & $\mathrm{NS}(\%)$ \\
\hline Pearl millet & 1.03 & 120.00 & 121.67 & 22.31 \\
& $( \pm 0.03)^{\mathrm{e}}$ & $( \pm 0.00)^{\mathrm{e}}$ & $( \pm 2.89)^{\mathrm{e}}$ & $( \pm 0.82)^{\mathrm{e}}$ \\
Soybean & 1.85 & 240.00 & 160.00 & 89.24 \\
& $( \pm 0.05)^{\mathrm{a}}$ & $( \pm 0.00)^{\mathrm{a}}$ & $( \pm 0.00)^{\mathrm{a}}$ & $( \pm 0.41)^{\mathrm{a}}$ \\
$5 \%$ & 1.22 & 143.33 & 130.00 & 51.67 \\
supplement & $( \pm 0.03)^{\mathrm{d}}$ & $( \pm 5.77)^{\mathrm{d}}$ & $( \pm 0.00)^{\mathrm{d}}$ & $( \pm 0.58)^{\mathrm{d}}$ \\
$10 \%$ & 1.45 & 163.33 & 138.33 & 71.08 \\
supplement & $( \pm 0.05)^{\mathrm{c}}$ & $( \pm 5.77)^{\mathrm{c}}$ & $( \pm 2.89)^{\mathrm{c}}$ & $( \pm 0.80)^{\mathrm{c}}$ \\
$15 \%$ & 1.62 & 180.00 & 150.00 & 82.16 \\
supplement & $( \pm 0.03)^{\mathrm{b}}$ & $( \pm 0.00)^{\mathrm{b}}$ & $( \pm 0.00)^{\mathrm{b}}$ & $( \pm 0.37)^{\mathrm{b}}$ \\
\hline
\end{tabular}

Values are means $( \pm \mathrm{SD})$. Means not sharing a common superscript letter in a column are significantly different at $\mathrm{P} \leq 0.05$.

$0.55 \mathrm{~g} / \mathrm{ml}$ for defatted soybean meal and $0.57 \mathrm{~g} / \mathrm{ml}$ for soybean flour which were lower than those obtained in this study. The differences in the values of bulk density between this study and previous ones are likely due to product and varietal differences [22]. Bulk density depends on interrelated factors including intensity of attracttive inter particle forces, particle size and number of contact points [23]. The water absorption capacity (WAC) of pearl millet was improved to $143 \mathrm{ml} \mathrm{H}_{2} \mathrm{O} / 100 \mathrm{~g}, 163$ $\mathrm{ml} \mathrm{H}_{2} \mathrm{O} / 100 \mathrm{~g}$ and $180 \mathrm{ml} \mathrm{H}_{2} \mathrm{O} / 100 \mathrm{~g}$ with increasing the level of soybean supplementation to $5 \%, 10 \%$ and $15 \%$, respectively. Narayana \& Narasinga Rao [24] reported that soya flour had WAC of $310 \mathrm{~g} / 100 \mathrm{~g}$ flour, while Kinsella [25], reported a value of $275 \mathrm{~g} / 100 \mathrm{~g}$ flour. The results obtained indicated that soybean flour had high WAC which contributed to the improvement of WAC of pearl millet. WAC is considered a critical function of protein in viscous foods, like soups, gravies, doughs and baked products [26]. The fat absorption capacity (FAC) of pearl millet was significantly $(\mathrm{P} \leq 0.05)$ improved with increase in the level of soybean supplementation to $130 \mathrm{ml}$ oil $/ 100 \mathrm{~g}$ flour, $138 \mathrm{ml}$ oil $/ 100 \mathrm{~g}$ flour and $150 \mathrm{ml}$ oil/100 $\mathrm{g}$ for the levels, respectively. Sosulski et al. [27] reported that FAC of soybean flour was $138 \%$, while Lin et al. [7] reported that it ranged between $84 \%$ and $133 \%$. The value of $120 \mathrm{~g} / 100 \mathrm{~g}$ flour was reported by Narayana \& Narasinga Rao [24]. The results obtained indicated that soybean flour had a good oil absorption capacity which would contribute to improve that of pearl millet. The ability of proteins to bind fats is important, since fats act as flavor retainers and increase the mouth feel of foods [28].

Many important properties of food involve the interactions of proteins and lipids, e.g., emulsion, fat entrapment in meats and fat absorption. The nitrogen solubility (NS) was significantly $(\mathrm{P} \leq 0.05)$ improved from $22.31 \%$ to
$82.16 \%$ for pearl millet with increasing the level of soybean supplementation to $15 \%$. The results obtained showed that supplementation of pearl millet with soybean protein significantly $(\mathrm{P} \leq 0.05)$ improved nitrogen solubility of pearl millet. McWatters \& Holms [29] reported that nitrogen solubility of soybean flour was $98 \%$. This result indicated that soybean flour had high nitrogen solubility and it would be expected to improve nitrogen solubility of pearl millet as a result of supplementation. Solubility of protein is one of the critical functional attributes in food processing, because solubility greatly influences other properties, such as emulsification, gelation and foaming [9]. Pearl millet, like other cereals, has some limitations due to its low content of protein and some essential amino acids, such as lysine. Recent studies indicated that supplementation of wheat and maize food products with soy bean improve the nutritional quality of proteins, and sensory and rheological properties $[30,31]$.

\subsection{Dispersibility}

The dispersibilisty of pearl millet, soybean flour and pearl millet supplemented with soybean flour is shown in Table 2. The results indicated that soybean flour had higher dispersibility than pearl millet flour. Also, the dispersibility for both was higher at higher acidic $\mathrm{pH}$ than neutral and the protein dispersibility of soybean products is lowest at $\mathrm{pH} 4.5$ (the isoelectric point of soybean proteins) and at $\mathrm{pH}$ value above and below the isoelectric region, the mean protein dispersibility increased significantly. As shown in Table 2 the dispersebility of pearl millet flour increased significantly $(\mathrm{P} \leq$ 0.05 ) with increasing the level of soybean protein supplement $(5 \%, 10 \%$ and $15 \%)$ and it was higher at acidic $\mathrm{pH}$ than neutral and alkaline $\mathrm{pHs}$. These results indicated that supplementation of pearl millet cultivar with soy-

Table 2. Effect of pH on dispersibility (\%) of defatted pearl millet flour, soybean flour and pearl millet supplemented with $5 \%, 10 \%$ and $15 \%$ soybean flour.

\begin{tabular}{cccc}
\hline \multirow{2}{*}{ Sample } & \multicolumn{3}{c}{ Dispersibility (\%) } \\
\cline { 2 - 4 } & \multicolumn{3}{c}{$\mathrm{pH}$} \\
& 3 & 7 & 10 \\
Pearl millet & 37.22 & 27.22 & 23.89 \\
& $( \pm 0.96)^{\mathrm{e}}$ & $( \pm 0.96)^{\mathrm{d}}$ & $( \pm 0.96)^{\mathrm{e}}$ \\
Soybean & 71.11 & 46.11 & 38.89 \\
& $( \pm 0.96)^{\mathrm{a}}$ & $( \pm 0.96)^{\mathrm{a}}$ & $( \pm 0.96)^{\mathrm{a}}$ \\
$5 \%$ supplement & 43.33 & 28.89 & 26.67 \\
& $( \pm 0.00)^{\mathrm{d}}$ & $( \pm 0.96)^{\mathrm{d}}$ & $( \pm 0.00)^{\mathrm{d}}$ \\
& 50.00 & 31.11 & 28.33 \\
$10 \%$ supplement & $( \pm 0.00)^{\mathrm{c}}$ & $( \pm 0.96)^{\mathrm{c}}$ & $( \pm 0.00)^{\mathrm{c}}$ \\
& 56.11 & 34.44 & 30.56 \\
$15 \%$ supplement & $( \pm 0.96)^{\mathrm{b}}$ & $( \pm 0.96)^{\mathrm{b}}$ & $( \pm 0.96)^{\mathrm{b}}$ \\
\hline
\end{tabular}

Values are means $( \pm \mathrm{SD})$. Means not sharing a common superscript letter in a column are significantly different at $\mathrm{P} \leq 0.05$. 
bean protein improved significantly $(\mathrm{P} \leq 0.05)$ the dispersibility of millet flour. The dispersibility of a mix in water indicates its reconstitutionability. The higher the dispersibility, the better the reconstitution property [16]. Higher dispersibility enhances the emulsifying and foaming properties of proteins, which was observed during making of bread, macaroni and cookies [25].

\subsection{Emulsifying Properties}

The emulsifying properties of pearl millet, soybean flour and pearl millet supplemented with soybean protein are shown in Table 3. The emulsifying capacity of pearl millet was poor $(7.47 \mathrm{ml}$ oil $/ \mathrm{gm}$ flour $)$ but addition of $15 \%$ soybean protein improved the emulsifying capacity significantly $(\mathrm{P} \leq 0.05)$ to $60.63 \mathrm{ml} \mathrm{oil} / \mathrm{gm}$ flour. The results indicated that soybean flour had high emulsifying capacity. Sosulski et al. [27] reported that soybean showed excellent oil emulsification $(82 \%$ at $\mathrm{pH} 6.5)$; while McWatters \& Holms [29] reported that the emulsifying capacity of soy flour was about five times that of peanut flour. Supplementation with soybean flour would be expected to improve the emulsifying capacity of pearl millet. The emulsifying activity was significantly $(\mathrm{P} \leq$ 0.05 ) improved for pearl millet from $11.79 \%$ to $45.84 \%$ with addition of $15 \%$ soybean protein. Yasumatsu et al. [12] and Volkert \& Klein [32] reported that dispersible nitrogen or protein correlates with emulsifying activity and emulsion stability. The emulsion stability (ES) of pearl millet was very low (7.67\%) but addition of $15 \%$ soybean protein improved it significantly $(\mathrm{P} \leq 0.05)$ to $41.14 \%$. The results obtained indicated that soybean had significantly $(\mathrm{P} \leq 0.05)$ improved the emulsion stability of pearl millet. Elzialde et al. [33] reported that the emulsion stability is enhanced by high protein and oil concentrations and these factors are highly interrelated. They also, reported that emulsion stability depends primarily upon the water and oil absorption capacity. Protein stabilized oil in water emulsions are to be found in various branches of food industry. These include milk, cream, salad dressing, mayonnaise, gravies and meat emulsions [34]. Also, McWatters \& Cherry [35] reported that the ability of a protein to aid the formation and stabilization of emulsion is critical for its application in preparation like butters, milk and frozen desserts. The emulsifying properties in general, play a significant role in many food systems including doughs, salad dressing, infant foods, ice-cream and coffee whiteners.

\subsection{Foaming Properties}

The foaming capacity (FC) and foam stability (FS) of pearl millet, soybean flour and pearl millet supplemented with soybean protein $(5 \%, 10 \%$ and $15 \%)$ is shown in Table 4. It was clear that soybean had high foam volume, while pearl millet had low one. Therefore, the foaming

Table 3. Emulsion capacity (EC), emulsifying activity (EA) and emulsion stability (ES) of defatted pearl millet flour, soybean flour and pearl millet supplemented with $5 \%, 10 \%$ and $15 \%$ soybean flour.

\begin{tabular}{cccc}
\hline Sample & EC ml oil/gm flour & EA (\%) & ES (\%) \\
\hline Pearl millet & $7.47( \pm 0.15)^{\mathrm{e}}$ & $11.79( \pm 1.02)^{\mathrm{e}}$ & $7.67( \pm 1.02)^{\mathrm{e}}$ \\
Soybean & $81.70( \pm 0.20)^{\mathrm{a}}$ & $56.65( \pm 1.28)^{\mathrm{a}}$ & $52.10( \pm 1.53)^{\mathrm{a}}$ \\
$5 \%$ supplement & $36.10( \pm 0.10)^{\mathrm{d}}$ & $32.02( \pm 0.96)^{\mathrm{d}}$ & $26.50( \pm 0.00)^{\mathrm{d}}$ \\
$10 \%$ supplement & $47.23( \pm 0.15)^{\mathrm{c}}$ & $39.34( \pm 1.01)^{\mathrm{c}}$ & $32.89( \pm 1.02)^{\mathrm{c}}$ \\
$15 \%$ supplement & $60.63( \pm 0.15)^{\mathrm{b}}$ & $45.84( \pm 0.00)^{\mathrm{b}}$ & $41.14( \pm 1.02)^{\mathrm{b}}$ \\
\hline
\end{tabular}

Values are means $( \pm \mathrm{SD})$. Means not sharing a common superscript letter in a column are significantly different at $\mathrm{P} \leq 0.05$.

Table 4. Foam capacity (FC\%) and foam stability (FS\%) of defatted pearl millet flour, soybean flour and pearl millet supplemented with $5 \%, 10 \%$ and $15 \%$ soybean flour.

\begin{tabular}{ccccccccc}
\hline & & \multicolumn{5}{c}{ FS $(\%)$} \\
\cline { 3 - 8 } & & \multicolumn{7}{c}{ Time $(\min )$} \\
\hline Sample & FC $(\%)$ & 0 & 15 & 30 & 45 & 60 & 75 & 90 \\
\hline Pearl millet & $24.00( \pm 1.00)^{\mathrm{e}}$ & $100.00( \pm 0.00)^{\mathrm{a}}$ & $47.22( \pm 1.21)^{\mathrm{e}}$ & $27.75( \pm 1.55)^{\mathrm{e}}$ & $22.07( \pm 1.10)^{\mathrm{d}}$ & $16.69( \pm 0.70)^{\mathrm{d}}$ & $15.24( \pm 1.93)^{\mathrm{d}}$ & $12.51( \pm 0.52)^{\mathrm{e}}$ \\
Soybean & $69.48( \pm 0.73)^{\mathrm{a}}$ & $100.00( \pm 0.00)^{\mathrm{a}}$ & $98.48( \pm 0.00)^{\mathrm{a}}$ & $94.95( \pm 0.87)^{\mathrm{a}}$ & $89.39( \pm 1.52)^{\mathrm{a}}$ & $84.34( \pm 0.88)^{\mathrm{a}}$ & $81.31( \pm 0.88)^{\mathrm{a}}$ & $75.76( \pm 1.52)^{\mathrm{a}}$ \\
$5 \%$ supplement & $49.15( \pm 0.29)^{\mathrm{d}}$ & $100.00( \pm 0.00)^{\mathrm{a}}$ & $66.90( \pm 0.39)^{\mathrm{d}}$ & $30.34( \pm 1.07)^{\mathrm{d}}$ & $23.58( \pm 1.67)^{\mathrm{d}}$ & $17.93( \pm 1.11)^{\mathrm{d}}$ & $16.56( \pm 0.20)^{\mathrm{d}}$ & $14.48( \pm 0.17)^{\mathrm{d}}$ \\
$10 \%$ supplement & $59.04( \pm 0.82)^{\mathrm{c}}$ & $100.00( \pm 0.00)^{\mathrm{a}}$ & $82.66( \pm 0.17)^{\mathrm{c}}$ & $47.40( \pm 0.87)^{\mathrm{c}}$ & $33.52( \pm 0.88)^{\mathrm{c}}$ & $22.54( \pm 0.23)^{\mathrm{c}}$ & $19.08( \pm 0.19)^{\mathrm{c}}$ & $16.76( \pm 0.84)^{\mathrm{c}}$ \\
$15 \%$ supplement & $66.90( \pm 0.52)^{\mathrm{b}}$ & $100.00( \pm 0.00)^{\mathrm{a}}$ & $93.88( \pm 0.05)^{\mathrm{b}}$ & $91.33( \pm 0.85)^{\mathrm{b}}$ & $84.70( \pm 0.13)^{\mathrm{b}}$ & $78.57( \pm 0.19)^{\mathrm{b}}$ & $69.90( \pm 0.79)^{\mathrm{b}}$ & $63.78( \pm 0.78)^{\mathrm{b}}$ \\
\hline
\end{tabular}

Values are means $( \pm \mathrm{SD})$. Means not sharing a common superscript letter in a column are significantly different at $\mathrm{P} \leq 0.05$. 
capacity of pearl millet significantly $(\mathrm{P} \leq 0.05)$ improved after addition of soybean protein. As shown in Table 4, the foam of soybean flour was significantly stable than that of pearl millet. Also, it was clear that foam stability of pearl millet significantly $(\mathrm{P} \leq 0.05)$ improved with increasing the level of soybean supplementation. Soybean flour had high foam volume and it appeared to be a promising source of protein for use in whipped food products [27]. Foam stability is important since the usefulness of whipping agents depends on their abilities to maintain the whip as long as possible [7]. Stability was related to denaturation of the stabilized protein [12],

\subsection{Least Gelation Concentration}

The least gelation concentration of pearl millet, soybean flour and pearl millet supplemented with soybean protein is shown in Table 5. Pearl millet flour formed a weak gel at $6 \%$, while a strong gel was formed at $8 \%$ and a very strong gel at $10 \%$. No gel was formed at $2 \%$ and $4 \%$ concentrations. Soybean flour formed a very weak gel at $8 \%$, while a weak gel was formed at $10 \%$. No gel was formed at $2 \%, 4 \%$ or $6 \%$ concentrations. The results obtained indicated that pearl millet flour level of concentration for gelation was significantly $(\mathrm{P} \leq 0.05)$ lower than that of soybean flour, because pearl millet flour contained starch, which induced gelation due to starch-starch and/or starch-protein interactions. Sosulski et al. [27] reported that the small proportion of soybean flour gel was particularly soft and remained relatively fluid. Pearl millet supplemented with $5 \%$ soybean protein formed a very weak gel at $6 \%$, while a weak gel was formed at $8 \%$ and a strong gel at $10 \%$. No gel was formed at $2 \%$ or $4 \%$ levels of concentration. Pearl millet supplemented with $10 \%$ and $15 \%$ soybean protein formed a very weak gel at $10 \%$ and no gel was formed at $2 \%, 4 \%$ or $8 \%$ levels of concentration for both. These results indicated that pearl millet flour when supplemented with soybean required a

Table 5. Least gelation concentration of defatted pearl millet flour, soybean flour and pearl millet supplemented with $5 \%, 10 \%$ and $15 \%$ soybean flour.

\begin{tabular}{cccccc}
\hline & \multicolumn{5}{c}{ Concentration (\%) } \\
\cline { 2 - 6 } Sample & 2 & 4 & 6 & 8 & 10 \\
\hline Pearl millet & - & - & + & ++ & +++ \\
Soybean & - & - & - & \pm & + \\
$5 \%$ supplement & - & - & \pm & + & ++ \\
$10 \%$ supplement & - & - & - & - & \pm \\
$15 \%$ supplement & - & - & - & - & \pm \\
\hline
\end{tabular}

- No gel; \pm Very weak gel; + Weak gel; ++ Strong gel; +++ Very strong gel. higher flour concentration than pearl millet flour for gelation because the starch content decreased due to fortification with soybean flour. These results were in agreement with those reported by Singh \& Singh [36], who compared the gelation capacity of partially defatted peanut flour. Kinsella [25] reported that the gelation property of proteins is basic for many oriental textured foods, e.g. tofu, cheese, custards and various meat products.

\section{Conclusion}

Supplementation of pearl millet flour with soybean protein had significantly improved the functional properties of pearl millet flour. The improvement in the functional properties of pearl millet flour after supplementation makes it a useful ingredient for several food products.

\section{REFERENCES}

[1] FAO, "Sorghum and Millets in Human Nutrition," Food and Nutrition Series, No. 27, Food and Agriculture Organization of the United Nations, Rome, 1995.

[2] J. L. Collins and G. A. Falasinnu, "Yam (Ciscorea spp.) Flour Fortification with Soy Flour," Journal of Food Science, Vol. 42, No. 3, 1977, pp. 821-823. doi:10.1111/j.1365-2621.1977.tb12612.x

[3] R. O. Fennema, "Food Chemistry," 3rd Edition, Marcel Dekker Inc., New York, 1996, pp. 365-396.

[4] K. C. Rhee, "Peanuts (Groundnuts)," In: A. M. Altschul and H. L. Wilcle, Eds., New Protein Foods, Seed Storage Proteins, Academic Press, New York, Vol. 5, 1985, pp. 359-391.

[5] M. Yim and J. Lee, "Functional Properties of Fractionated Soy Protein Isolates by Proteases from Meju," Food Science Biotechnology, Vol. 9, 2000, pp. 253-257.

[6] W. J. Wolf, "Soybeans Proteins: Their Functional, Chemical and Physical Properties," Journal of Agricultural Food Chemistry, Vol. 18, No. 6, 1970, pp. 969-976. doi:10.1021/jf60172a025

[7] M. J. Y. Lin, E. S. Humbert and F. W. Sosulski, "Certain Functional Properties of Sunflower Meal Products," Journal of Food Science, Vol. 39, No. 2, 1974, pp. 368-370. doi:10.1111/j.1365-2621.1974.tb02896.x

[8] M. R. Quinn and L. R. Beuchat, "Functional Property Changes Resulting from Fungal Fermentation of Peanut Flour," Journal of Food Science, Vol. 40, No. 3, 1975, pp. 475-479. doi:10.1111/j.1365-2621.1975.tb12508.x

[9] J. C. Wang and J. E. Kinsella, "Functional Properties of Novel Proteins: Alfalfa Leaf Protein," Journal of Food Science, Vol. 41, No. 2, 1976, pp. 286-292. doi:10.1111/j.1365-2621.1976.tb00602.x

[10] R. Hagenmaier, "Water Binding of Some Purified Oil Seed Proteins," Journal of Food Science, Vol. 37, No. 6, 1972, pp. 965-966. doi:10.1111/j.1365-2621.1972.tb03716.x

[11] L. R. Beuchat, J. B. Cherry and M. R. Quinn, "Physico- 
chemical Properties of Peanut Flour as Affected By Proteolysis," Journal of Agricultural Food Chemistry, Vol. 23, No. 4, 1975, pp. 616-620. doi:10.1021/jf60200a045

[12] K. Yasumatsu, K. Sawada, S. Moritaka, M. Misaki, J. Toda, T. Wada and K. Ishii, "Whipping and Emulsifying Properties of Soybean Products," Agricultural and Biological Chemistry, Vol. 36, No. 5, 1972, pp. 719-724. doi:10.1271/bbb1961.36.719

[13] J. T. Lawhon, C. N. Cater and K. F. Mattil, "A Comparative Study of the Whipping Potential of an Extract from Several Oil Seed Flours," Cereal Science Today, Vol. 17, No. 4, 1972, pp. 240-244.

[14] E. A. Ahmed and R. H. Schmidt, "Peanut and Soybean Pro- teins as Influenced by Processing," Peanut Science, Vol. 6, No. 1, 1979, pp. 1-5. doi:10.3146/i0095-3679-6-1-1

[15] C. W. Coffman and V. V. Garcia, "Functional Properties and Amino Acid Content of a Protein Isolate from Mung Bean Flour," Journal of Food Technology, Vol. 12, No. 5, 1977, pp. 473-478. doi:10.1111/j.1365-2621.1977.tb00132.x

[16] K. D. Kulkarni, D. N. Kulkarni and U. M. Ingle, "Sorghum Malt Based Weaning Food Formulations: Preparation, Functional Properties and Nutritive Value," Food Nutrition Bulletin, Vol. 13, No. 4, pp. 4324-4327.

[17] J. M. Regenstein and C. E. Regenstein, "Food Protein Chemistry," Academic Press Inc., New York, 1984.

[18] G. W. Snedecor and W. G. Cochran, "Statistical Methods," 17th Edition, The Iowa State University Press, Ames, 1987, pp. 221-222.

[19] B. O. Duncan, "Multiple Range and Multiple F Test," Biometrics, Vol. 11, No. 1, 1955, pp. 1-42. doi: $10.2307 / 3001478$

[20] T. S. Padmashree, L. Vijayalakshmi and S. Puttaraj, "Effect of Traditional Processing on the Functional Properties of Cowpea (Vigna catjang) Flour," Journal of Food Science and Technology, Vol. 24, No. 5, 1987, pp. 221224.

[21] J. E. Densh, "Extraction of Nitrogenous Material from Winged Bean [Psophocarpus tetragonolotus (L.) DC] Flour and the Preparation and Properties of Protein Isolates," Journal of the Science Food and Agriculture, Vol. 33, No. 2, 1982, pp. 173-184. doi:10.1002/jsfa.2740330209

[22] L. A. Bryant, J. Montecalvo, J. R. Morey and K. S. Loy, "Processing, Functional and Nutritional Properties of Okra Seed Products," Journal of Food Science, Vol. 53, No. 3, 1988, pp. 810-816. doi:10.1111/j.1365-2621.1988.tb08960.x

[23] M. Peleg and E. B. Bagley, "Physical Properties of Foods," AVI Publishing Co. Inc., Westport, 1983.

[24] K. Narayana and M. S. Narasinga Rao, "Functional Properties of Raw and Heat Processed Winged Bean (Psophocarpus tetragonolobus) Flour," Journal of Food Sci- ence, Vol. 47, No. 5, 1982, pp. 1534-1538. doi:10.1111/j.1365-2621.1982.tb04976.x

[25] J. E. Kinsella, "Functional Properties of Soy Proteins," Journal of American Oil Chemists Society, Vol. 56, No. 3, 1979, pp. 242-249. doi:10.1007/BF02671468

[26] F. W. Sosulski, E. S. Humbert, K. Bui and J. D. Jones, "Functional Properties of Rape Seed Flour, Concentrates and Isolates," Journal of Food Science, Vol. 41, No. 6, 1976, pp. 1349-1352. doi:10.1111/j.1365-2621.1976.tb01168.x

[27] F. W. Sosulski, M, D. Garratt and A. E. Slinkard, "Functional Properties of Ten Legume Flours," Institute of Food Science and Technology Journal, Vol. 9, No. 2, 1976, pp. 66-69.

[28] J. E. Kinsella, "Functional Properties of Proteins in Foods, a Survey," Critical Review of Food Science and Nutrition, Vol. 7, No. 3, 1976, pp. 219-222. doi: $10.1080 / 10408397609527208$

[29] K. H. McWatters and M. R. Holmes, "Influence of Moist Heat on Solubility and Emulsification Proteins of Soy and Peanut Flours" Journal of Food Science, Vol. 44, No. 3, 1979, pp. 774-776. doi:10.1111/j.1365-2621.1979.tb08498.x

[30] E. K. Ingbian and G. O. Adegoke, "Nutritional Quality of Protein Enriched Mumu-A Traditional Cereal Food Product," International Journal of Food Science and Technology, Vol. 42, No. 4, 2007, pp. 385-501. doi:10.1111/j.1365-2621.2007.01229.x

[31] M. Mashayekh, M. R. Mahmoodi and M. H. Entezari, "Effect of Supplementation of Defatted Soy Flour on Sensory and Rheological Properties of Wheat Bread," International Journal of Food Science and Technology, Vol. 43, No. 9, 2008, pp. 1693-1698.

[32] M. A. Volkert and B. P. Klein, "Protein Dispersibility and Emulsion Characteristics of Four Soy Products," Journal of Food Science, Vol. 44, No. 1, 1979, pp. 93-96. doi:10.1111/j.1365-2621.1979.tb10014.X

[33] B. E. Elzialde, A. M. R. Pilosof and G. B. Bartholomi, "Prediction of Emulsion Instability from Emulsion Proteins," Journal of Food Science, Vol. 56, No. 1, 1991, pp. 116-119. doi:10.1111/j.1365-2621.1991.tb07989.x

[34] E. Tornbery and A. M. Hermansson, "Functional Characterization of Protein Stabilized Emulsions: Effect of Processing," Journal of Food Science, Vol. 42, No. 2, 1977, pp. 468-472. doi:10.1111/j.1365-2621.1977.tb01524.x

[35] K. H. McWaters and J. P. Cherry, "Protein Functionality in Foods," In: J. P. Cherry, Eds., American Chemical Society Symposium Series, Vol. 147, 1981, p. 217.

[36] U. Singh and B. Singh, "Functional Properties of Sorghum-Peanut Composite Flour," Journal of Cereal Che- mistry, Vol. 68, No. 5, 1991, pp. 460-643. 